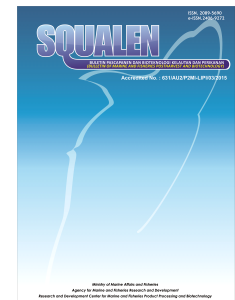

\title{
ANTIOXIDANT AND ACE INHIBITOR POTENTIAL OF STRIPE TREVALLY FISH (Selaroides leptolepis) HYDROLYSATE
}

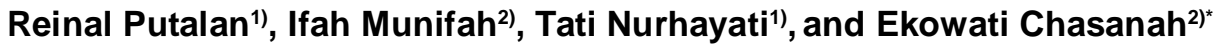 \\ ${ }^{1}$ Department of Aquatic Product Technology, Bogor Agricultural University, \\ Jalan Lingkar Akademik Kampus IPB Dramaga, Bogor 16680, Indonesia \\ ${ }^{2}$ Research and Development Center for Marine and Fisheries Product Processing and Biotechnology \\ JI. KS. Tubun Petamburan VI, Jakarta 10260 Indonesia \\ Article history: \\ Received: 20 January 2018; Revised: 3 March 2018; Accepted: 24 April 2018
}

\begin{abstract}
This study aimed to investigate the potency of fish protein hydrolysates (FPH) of stripe trevally fish (Selaroides leptolepis) as antioxidant and ACE inhibitor. The FPH was produced through enzymatically hydrolysis using protease produced by Bacillus licheniformis, a collection of Research and Development Center for Marine and Fisheries Product Processing and Biotechnology (RDCMFPPB). The FPH was fractionated using ultrafiltration membranes with molecular weight cut off (MWCO) of 10,5 and $3 \mathrm{kDa}$. The hydrolysis degree, protein content, peptide content, antioxidant activity and Angiotensin-converting enzyme (ACE) inhibitor were observed. The result showed that FPH had maximum hydrolysis degree of $63.91 \%$ reached after 6 hours hydrolysis with protein content of $27.43 \mathrm{mg} / \mathrm{mL}$ and peptide content of $223.32 \mathrm{mg} / \mathrm{mL}$. That FPH showed antioxidant activity $\left(\mathrm{IC}_{50}\right)$ of $1941.06 \mathrm{ppm}$ and ACE inhibitor of $87.82 \%$ at test concentration of $10 \mathrm{mg} / \mathrm{mL}$. In the ultrafiltration step, the higher molecular cut off used, the higher protein content and peptide content. The lower molecular weight of the hydrolysate, the better antioxidant and ACE inhibitor activity. The best fractionation that produce potential product to be used as anti-hypertension was in mixture peptides between 3-5 kDa. The $\mathrm{IC}_{50}$ antioxidant activity was $1336.96 \mathrm{ppm}$ and percentage of ACE inhibitor was $97.15 \% \%$ (with a concentration of $10 \mathrm{mg} / \mathrm{mL}$ ). From the results, protein hydrolysate of stripe trevally fish produced by enzymatic hydrolysis using local protease was potential as a functional ingredient, particularly as antihypertensive agent.
\end{abstract}

Keyword: antioxidant, ACE inhibitor, stripe trevelly, protein hydrolysate, ultrafiltration

\section{Introduction}

Fish protein hydrolysate (FPH) is a product produced by protein hydrolysis process. Protein hydrolysis are made by cutting peptide bonds on proteins using acids, bases or enzymes (Adler-Nissen 1986). Among those methods, enzymatic hydrolysis is preferable because enzymatic reactions are not extreme, easy to control, minimize by-products formation and do not reduce the nutritional value of the protein. The hydrolysis result is mixed of shorter protein, peptide, and free amino acid.

According to Murray and FitzGerald (2007), peptides is potential as antioxidant and antihypertensive. Antioxidants are compounds that capable to inhibit the oxidation processes (Valko et al., 2007). Based on the source, the antioxidants are divided into two, i.e natural and synthetic. Natural antioxidants can be obtained from food sources such as vitamin $\mathrm{C}$, vitamin $\mathrm{E}$, phenolic compounds, and flavonoids, while synthetic antioxidants such as butylated hydroxyanisole (BHA), butylated hydroxytoluene (BHT), tertiary butylhydroquinone (TBHQ) and propyl gallate. The use of synthetic antioxidants in food needs strict standards, as they are potentially harmful to health (Park, Jung, Nam, Shahidi, \& Kim, 2001). Meanwhile, hypertension is a disease caused by the unbalanced mechanism of renin angiotensinogen in the body. Renin catalyzes the angiotensinogen substrates that are produced by liver into the active compound angiotensin I. These compounds are subsequently catalyzed by the enzyme ACE (angiotensin-I converting enzyme) from the lungs into angiotensin II. Changes in angiotensin I to II lead to increase the aldosterone secretion, sympathetic nervous activity, salt retention, and

${ }^{*}$ Corresponding author.

E-mail: ekowatichasanah@gmail.com 
vasoconstriction of blood vessels to increase (Kearney et al. 2005).

Antioxidants and ACE inhibitors are present naturally in most food ingredients (Baehaki, Lestari, \& Romadhoni, 2015). Several studies on antioxidant activity and ACE inhibitors from protein hydrolysate have been performed. Klompong et al. (2009) have reported hydrolysis of stripe trevally fish using alcalase enzyme and produced peptide that was potential as antioxidant. Hydrolysis of sardines using alcalase enzymes conducted by Bougatef et al. (2010) has resulted peptides with antioxidant activity. Ji, Zhang, $\mathrm{Li}$, Zhao and Zhou (2011) reported hydrolysis of Pseudosciaena polyactis using alcalase enzyme produced a peptide with antioxidant activity of $\mathrm{IC}_{50}$ 1784 ppm. Khirzin, Sukarno, Yuliana, Fawzya and Chasanah (2015) reported peptides of sea cucumbers hydrolysate, which were hydrolysed using papain enzyme, showed ACE inhibitor activity of $82.31 \%$ using 10.000 ppm concentration. Toopcham, Mes, Wichers, Roytrakul, and Yongsawatdigul (2017) reported peptides from tilapia hydrolysate, hydrolysed using $V$. halodenitrificans protease, can inhibit ACE by $89.3 \%$ with $\mathrm{IC}_{50}$ value of $0.29 \mu \mathrm{M}$. Ahn, Jeon, Kim, and Je (2012) reported the use of alcalase enzymes to hydrolyse salmon byproducts and obtaining 3 purified peptides with ACE inhibitor activity having $\mathrm{IC}_{50}$ value of $7.72 \mu \mathrm{M}, 9.10 \mu \mathrm{M}$ and $10.77 \mu \mathrm{M}$.

This study aimed to investigate the potential of enzymatically hydrolyzed stripe trevally fish (Selaroides leptolepis) as antioxidants and ACE inhibitor.

\section{Materials and Methods}

The fish used for the study was obtained from Muara Angke market. Preparation of FPH from stripe trevally fish was conducted using protease produced by RDCMFPPB. The FPH was fractionated using ultrafiltration membranes with MWCO of 10,5 and 3 $\mathrm{kDa}$. Degree of hydrolysis of protein $(\mathrm{DH})$ (Hoyle \& John,1994), antioxidant activity (Li et al., 2006), ACE inhibitors (Nakamura et al., 1995), protein content (Lowry, Rosbrough, Farr, \& Randall, 1951) and peptide content (Church, Swaisgood, Porter, \& Catignani, 1983) were conducted to characterize the FPH. Vitamin $\mathrm{C}$ was used as antioxidant control (7.38 ppm), while captopril was used as positive control of ACE inhibitor in concentration of its application, ie. $10 \mathrm{mg} /$ $\mathrm{mL}$.

The experiment was conducted in triplicates. All data were analyzed using completely randomized design, except antioxidant activity was analyzed descriptively. The data obtained were then analyzed using ANOVA with Duncan's advanced test at 5\% level using software SPSS version 16.

\subsection{Preparation of Stripe Trevally Fish Protein Hydrolysate}

Fish flesh was chopped and blended with water (ratio 1:2 w/v). Protease enzyme (500 U/25g of meat) was added, then hydrolysed at $55^{\circ} \mathrm{C}$. Hydrolysis process was conducted gradually at $0,3,5,6,7,8$ and 9 hours, followed with enzyme inactivation at 80 $90^{\circ} \mathrm{C}$ for 20 minutes. The supernatant $(\mathrm{FPH})$ was obtained by separation using centrifuge $(8000 \mathrm{x} \mathrm{g})$ for 10 minutes.

\subsection{Fractionation with Ultrafiltration Membrane}

The protein hydrolysate was fractionated using ultrafiltration membranes with molecular weight cut off (MWCO) of 10,5 and $3 \mathrm{kDa}$ at $10 \mathrm{psi}, 20^{\circ} \mathrm{C}$. The fractions obtained were then characterized.

\section{Results and Discussion}

\subsection{Characteristics of Fish Protein Hydrolysate}

In the process of making protein hydrolysate, one of which needs to be considered is the flavor generated by the hydrolysate it self. Based on the literature study, the selection of enzymes used has an influence in causing a bitter taste of protein hydrolysate. Research conducted by Hoyle and John (1994) reported that herring protein hydrolysate using papain enzyme produced FPH that was bitter compared with that produced using alcalase. In this study, bitter-free hydrolysate was used as screening of choosing the protease-producing microbes used in this study. $B$. licheniformis protease produced bitter-free FPH was finally chosen. The bitter taste of the product related to the hydrophobic amino acid residues (FitzGerald \& Cuinn, 2006).

The characteristics of the stripe trevally fish (Selaroides leptolepis) protein hydrolysate obtained by enzymatically hydrolysis using protease are shown in Table 1. The results showed that the optimum hydrolysis degree was reached after 6 hours (63.91\%). It produced FPH with highest protein and peptide content, best antioxidant activity and ACE inhibitor value. The duration of hydrolysis had a significant effect on the degree of hydrolysis $(p<0.05)$. Along the hydrolysis process, the degree of hydrolysis was increased until 6 hours and then decrease. The degree of hydrolysis $(\mathrm{DH})$ describes the percentage of cleaved peptide bonds during hydrolysis and resulting in short peptides (Nielsen, Petersen, \& Dambmann, 2001). 
Table 1. Characteristics of FPH

\begin{tabular}{ccccccc|}
\hline $\begin{array}{c}\text { Time of hydrolysis } \\
\text { (hour) }\end{array}$ & DH (\%) & $\begin{array}{c}\text { Protein } \\
(\mathbf{m g} / \mathbf{m L})\end{array}$ & $\begin{array}{c}\text { Peptide } \\
(\mathbf{m g} / \mathbf{m L})\end{array}$ & $\begin{array}{c}\text { Antioxidant } \\
\text { IC } \text { (50 }_{(\mathbf{p p m})}\end{array}$ & $\begin{array}{c}\text { ACE } \\
\text { Inhibitor (\%) }\end{array}$ \\
\hline 0 & $27.49^{\mathrm{d}}$ & $12.04^{\mathrm{e}}$ & $177.74^{\mathrm{e}}$ & 4661.92 & $67.73^{\mathrm{c}}$ \\
3 & $45.77^{\mathrm{c}}$ & $17.26^{\mathrm{d}}$ & $197.43^{\mathrm{d}}$ & 2990.99 & $56.70^{\mathrm{d}}$ \\
5 & $53.30^{\mathrm{b}}$ & $24.77^{\mathrm{c}}$ & $207.23^{\mathrm{b}}$ & 3163.75 & $81.82^{\mathrm{b}}$ \\
6 & $63.91^{\mathrm{a}}$ & $27.43^{\mathrm{a}}$ & $223.32^{\mathrm{a}}$ & 1941.06 & $87.82^{\mathrm{a}}$ \\
7 & $54.39^{\mathrm{b}}$ & $26.28^{\mathrm{b}}$ & $207.18^{\mathrm{b}}$ & 2077.88 & $80.03^{\mathrm{b}}$ \\
\hline \multirow{2}{*}{ Control $(+)$} & $51.59^{\mathrm{b}}$ & $25.37^{\mathrm{c}}$ & $203.48^{\mathrm{c}}$ & 2843.25 & $80.69^{\mathrm{b}}$ \\
& Captopril & - & - & - & - & $91.69^{\mathrm{b}}$ \\
\hline
\end{tabular}

Note. different alphabet indicates significant difference $(P<0.05)$

The use of different enzymes and raw materials (substrate) also affects the optimum hydrolysis time of fish protein. Nurhayati, Salamah, and Hidayat (2007) reported the optimum DH of stripe trevally fish using papain enzyme was reached at 6 hours. Nurhayati, Salamah, Cholifah, and Nugraha (2014) reported that highest $\mathrm{DH}$ of papain enzyme for lates calcarifer was achieved at 4 hours of hydrolisis time. Moreover, Nurhayati, Desniar, and Suhandana (2013) also reported that optimum $\mathrm{DH}$ of tuna heads using papain enzyme achieved at 3 hours of hydrolisis time.

The results (Table 1) showed that time of hydrolysis significantly affected the protein content yield $(P<0.05)$. After 6 hours of hydrolysis (the optimum $\mathrm{DH}$ ), the protein content was increased from 12.04 to $27.43 \mathrm{mg} / \mathrm{mL}$. Nurhayati et al. (2007) reported that hydrolisis of the Caranx leptolepis FPH using papain enzyme increased the protein content from $64.27 \%$ to $66.17 \%$ (dry basis). Thus it can be concluded that all the proteins present in the raw materials (fish) were converted into the dissolved proteins. The increasing protein content of hydrolysate products was occurred because, during the hydrolysis process, the waterinsoluble proteins are transformed into simpler compounds such as peptides and amino acids (Ovissipour, Safari, Motamedzadegan, \& Shabanpour, 2009).

Along with the increased of the $\mathrm{DH}$, the peptide content is also increased. The highest peptide content achieved at 6 hours treatment which also the optimum $\mathrm{DH}$. The results obtained are in line with those reported by Nielsen et al. (2001) that the levels of soluble proteins and peptides increase as the degree of hydrolysis increases. In this study, peptide content was analysed based on free amino acid present in the mixture using O-pthalaldehyde (OPA) method
(Mahmod et al., 2011), while the protein content was analysed based on Lowry method which measure peptide bond of protein. That is the reason why the peptide content resulted from protein hydrolysis was much higher than the protein content itself.

The best antioxidant activity was also obtained at 6 hours hydrolysis with $\mathrm{IC}_{50}$ of $1941.06 \mathrm{ppm}$. During hydrolysis process, a peptide bond is cleaved and numbers of amino acids are freed. He, Cao, Zhao, and Zhang (2013) reported that on the hydrolysis process, the proteins that are susceptible to oxidation are released into new peptides with a specific sequence. Hydrophobic amino acids such as methionine, proline, phenylalanine, and tryptophan can increase the activity of antioxidant peptides (Ren et al., 2008).

The results of the ACE inhibitor activity test showed that the protein hydrolysate from each sample had a significant $(p<0.05)$ difference of capabilities (Table 1$)$. $\mathrm{FPH}$ product (6-h hydrolysis) in concentration of 10 $\mathrm{mg} / \mathrm{mL}$ inhibited $87 \%$ ACE activity. In 0 hour treatment, ACE inhibitor activity is higher than the 3 hours treatment but lower than 5-9 hours treatment. It may relate to the size and structure of the peptides resulting from the hydrolysis process. Mirdhayati, Hermanianto, Wijaya, Sajuthi, and Arihara, (2015) reported that a lower degree of hydrolysis lead the contained peptide in the hydrolysate to be larger so that the affinity towards the ACE active side becomes weak. The results of the analysis showed that the duration of hydrolysis had a significant effect on the ACE inhibitor $(p<0.05)$.

\subsection{Fractionation with Ultrafiltration Membrane}

The best FPH was then fractionated using ultrafiltration membranes with molecular weight cut 
off (MWCO) of 10, 5 and $3 \mathrm{kDa}$. Four (4) different fractions were obtained, i.e $>10 \mathrm{kDa}$, fraction of $10-5$ $\mathrm{kDa}$, fraction of 5-3 kDa and fraction $<3 \mathrm{kDa}$ (Table 2).

The difference in molecular weight gave a significant effect $(\mathrm{P}<0.05)$ on the protein and peptide content showed by Duncan's advanced test results. In the ultrafiltration process, the particles with greater molecular weight than the membrane cut off will be retained on the membrane surface (retentate) while smaller molecules will pass through the membrane (permeate) and collected as ultrafiltrate (Smith, 2017). The smaller size of the stripe trevally fish fractions, the smaller the protein content (Table 2). This result is in agreement with Riyanto, Uju \& Halimi (2012) that reported the protein content of the tuna hydrolysate tends to decrease after the ultrafiltration process from $0.42 \mathrm{mg} / \mathrm{mL}$ (retentate) to $0.14 \mathrm{mg} / \mathrm{mL}$ (permeate). Yadav et al. (2016) reported that residual protein content of whey fermentation decreased after ultrafiltration process from $27.7 \mathrm{~g} / \mathrm{L}$ (retentate) to 4.6 $\mathrm{g} / \mathrm{L}$ (permeate).

Large size of protein has a low bioactivity while the protein that has been hydrolyzed or with a smaller size will has better bioactivity (Mahmod et al., 2011). According to Clemente (2000); Kristinsson and Rasco (2000) in general, short-chain peptides of smaller molecular weights have higher bioactivity than proteins in their intact form. Small molecular weight peptides lead to high solubility and bioavailability (Hajirostamloo, 2010; Kristinsson \& Rasco, 2000). It will quickly spreads and be absorbed on the target surface (Gbogouri, Linder, Fanni, \& Parmentier, 2004).

Table 2 shows that the antioxidant activity of the 5-3 $\mathrm{kDa}$ fraction exhibited the smallest $\mathrm{IC}_{50}$ value (1336.96 ppm). Fractions with smaller MW potentially had better antioxidant activity. The positive control that was used as a comparison in this study was vitamin
C with an $\mathrm{IC}_{50}$ value of $7.38 \mathrm{ppm}$. When compared with vitamin $\mathrm{C}$, the protein hydrolysate from the fish studied was not potentially used as an antioxidant. The study of Ranathunga, Rajapakse \& Kim (2006) reported that the hydrolysis of conger eel (Conger myriaster) fractionated using ultrafiltration ( $>5 \mathrm{kDa}$, 3-5 kDa, 1-3 kDa and <1 kDa) resulted in the peptide with a molecular weight of $<1 \mathrm{kDa}$ which had an antioxidant activity of $79 \%$. Jun, Park, Jung \& Kim (2004) fractionated the yellow fin sole hydrolysate (Limanda aspera) using 30, 10, 5, 3, and $1 \mathrm{kDa}$ ultrafiltration and reported that the highest antioxidant activity was at the fraction of $5 \mathrm{kDa}$. Luo, Wang, Li, Chi, Zhang \& He (2013) reported that Sphyrna lewini hydrolysate using papain enzyme with ultrafiltration $(<1,1-3,3-10$, and $>10 \mathrm{kDa})$ produced a peptide with a molecular weight of $<1 \mathrm{kDa}$ and antioxidant activity of $25.76 \pm 1.20 \%$.

According to Table 2, a fraction of 3-5 kDa showed the highest ACE inhibitor value of $97 \%$. Based on this result, it was assumed that fractions with smaller MW have better activity. The statistical test showed that the difference in molecular weight had a significantly different effect $(P<0.05)$ on the ACE inhibitor. The positive control that used in this study was captopril in apllication concentration, i.e $10 \mathrm{mg} / \mathrm{mL}$. It means that fish hydrolysate produced in this study especially the one that is pure enough might potentially be used as hypertension treatment but weak as antioxidant.

Ngo, Vo, Ryu \& Kim (2016) reported that the hydrolysis of codified skin using pepsin enzyme and fractionated using several ultrafiltration $(<1 \mathrm{kDa}, 1-5$ $\mathrm{kDa}, 5-10 \mathrm{kDa}$ and $>10 \mathrm{kDa}$ ) resulted peptide with a molecular weight of $<1 \mathrm{kDa}$ which had ACE inhibitor activity of $70 \%$. Roslan, Siti, Yunos, \& Abdullah (2017) fractionated the protein hydrolysate from tilapia fish products (tail and boneheads) using alcalase and fractionated with 10 and $5 \mathrm{kDa}$, showing the $5 \mathrm{kDa}$ fraction had highest ACE inhibitor activity $(71.83 \%$

Table 2. Characterization of 4 fractions of FPH

\begin{tabular}{cccccc}
\hline \multicolumn{2}{c}{ Fraction (kDa) } & $\begin{array}{c}\text { Protein } \\
(\mathbf{m g} / \mathbf{m L})\end{array}$ & $\begin{array}{c}\text { Peptide } \\
(\mathbf{m g} / \mathbf{m L})\end{array}$ & $\begin{array}{c}\mathrm{IC}_{50} \text { Antioxidant } \\
(\mathbf{p p m})\end{array}$ & $\begin{array}{c}\text { ACE Inhibitor } \\
(\%)\end{array}$ \\
\hline$>10$ & $19.31^{\mathrm{a}}$ & $357.96^{\mathrm{a}}$ & 3099.33 & $63.87^{\mathrm{b}}$ \\
$-10-5$ & $14.21^{\mathrm{b}}$ & $235.68^{\mathrm{b}}$ & 2426.65 & $90.35^{\mathrm{a}}$ \\
$-5-3$ & $11.85^{\mathrm{c}}$ & $216.24^{\mathrm{d}}$ & 1336.96 & $97.16^{\mathrm{a}}$ \\
$<3$ & $9.00^{\mathrm{d}}$ & $226.10^{\mathrm{c}}$ & 1370.43 & $90.61^{\mathrm{a}}$ \\
\hline \multirow{2}{*}{ Control $(+)$} & Vit. C & - & - & 7.69 & - \\
& Captopril & - & - & - & 95.89 \\
\hline
\end{tabular}

Note: different alphabet indicates significant difference $(P<0.05)$ 
inhibition). Lee, Qian \& Kim (2010) study about tuna bone hydrolysate using a pepsin enzyme and fractionated with several ultrafiltration membrane $(<1$, $1-5,5-10 \mathrm{kDa}$ ). The resulted peptide of $1-5 \mathrm{kDa}$ molecular weight had the highest ACE inhibitor activity of $91.6 \%$ inhibition. Samaranayaka, Kitts, \& Li-Chan (2010) reported that the most ACE inhibitors were those with smaller MW, short chain peptides with amino acid residues 2-12 amino acids and polar containing some hydrophobic (aromatic or side chain branching) amino acids on the sequence.

Results of this study indicate that hydrolysate stripe trevally fish (Selaroides leptolepis) using local protease enzyme has peptides that is potential for (weak) antioxidants and ACE inhibitors. This peptide is expected to be used as functional food ingredient particularly as antihypertensive agent.

\section{Conclusion}

Fish protein hydrolysate which was produced using local protease enzyme showed the maximum hydrolysis degree at 6 hours. When fractionated, the $\mathrm{IC}_{50}$ of antioxidant activity and percentage of ACE inhibitor were, i.e $1336 \mathrm{ppm}$ and 63.87-97.15\%, respectively. Peptides in the fraction of 3-5 kDa had antioxidant activity and ACE inhibitors better than peptides of larger fractions. Protein hydrolysate of stripe trevally fish produced by enzymatical hydrolysis using local protease had a great potential as a functional food ingredient, particularly as antihypertensive agent, but weak antioxidant.

\section{Acknowledgement}

This study was supported by Research and Development Center for Marine and Fisheries Product Processing and Biotechnology, the Ministry of Marine Affairs and Fisheries, Republic of Indonesia.

\section{References}

Adler-Nissen. (1986). Enzymatic Hydrolysis Of Food Proteins. New York, US: Elsevier Applied Science Publisher.

Ahn, C.B., Jeon, Y.J., Kim, Y.T., \& Je, J.Y. (2012). Angiotensin I converting enzyme (ACE) inhibitory peptides from salmon byproduct protein hydrolysate by Alcalase hydrolysis. Process Biochemistry, 47(1), 2240-2245.

Baehaki, A., Lestari, S.D., \& Romadhoni, A.R. 2015. Hidrolisis protein ikan patin menggunakan enzim papain dan aktivitas antioksidan. Pengolahan Hasil Perikanan Indonesia, 18(3), 230-239.

Bougatef, A., Naima, N.A., Manni, L., Ravallec, R., Barkia, A., Guillochon, D., \& Nasri, M. (2010). Purification and identification of novel antioxidant peptides from enzymatic hydrolysates of sardinelle (Sardinella aurita) by-products proteins. Food Chemistry, 118(3), 559-565.
Church, F.C., Swaisgood, H.E., Porter, D.H., \& Catignani, G.L. (1983). Spectrophotometric assay using Ophthaldialdehyde for determination of proteolysis in milk and isolated milk proteins. Dairy Science, 66(6), 1219-1227.

Clemente, A. (2000). Enzymatic protein hydrolysates in human nutrition. Trends in Food Science and Technology, 11, 254-262.

FitzGerald, R.J., \& Cuinn, G.O. (2006). Enzymatic debittering of food protein hydrolysates. Biotechnology Advances, 24(2), 234-240.

Gbogouri, G., Linder, M., Fanni, J., \& Parmentier, M. (2004). Influence of hydrolysis degree on the functional properties of salmon byproducts hydrolysates. Food Science, 69, 615-622.

He, X.Q., Cao, W.H., Zhao, Z.K., \& Zhang, C.H. (2013). Analysis of protein composition and antioxidant activity of hydrolysate from Paphia undulate. Food and Nutrition Research, 1(3), 30-36.

Hoyle, N.T., \& John, H.M. (1994). Quality of fish protein hydrolysates from Herring (Clupea Harengus). Food Science, 59(1), 76-79.

Hajirostamloo, B. (2010). Bioactive component in milk and dairy product. World Academy of Science Engineering and Technology, 72, 162-166.

Ji, Y., Zhang, G., Li, X., Zhao, B., \& Zhou, S. (2011). Enzymatic hydrolysis of protein from small yellow croaker (Psendosciaena polyactis) and evaluation of its antioxidant activity. Food Biochemistry, 37(3), 278285.

Jun, S.Y., Park, P.J., Jung ,W.K., \& Kim, S.K. (2004). Purification and characterization of an antioxidative peptide from enzymatic hydrolysate of yellowfin sole (Limanda aspera) frame protein. European Food Research and Technology, 219(1), 20-26.

Kearney, P.M., Whelton, M., Reynold, K., Muntner, P., Whelton, P.K., \& He, J. (2005). Worldwide prevalence of hypertension: A systematic review. Hypertension, 22(1), 11-19.

Khirzin, M.H., Sukarno, Yuliana, N.D., Fawzya, Y.N., \& Chasanah, E. (2015). The activity of Angiotensin Converting Enzyme (ACE) Inhibitor and collagen peptide antioxidant from gama sea cucumber (Stichopus variegatus). JPB Kelautan dan Perikanan, 10(1), 27-35.

Klompong, V., Benjakul, S., Yachai, M., Visessanguan, W., Shahidi, F., \& Hayes, K.D. (2009). Amino acid composition and antioxidative peptides from protein hydrolysates of yellow stripe trevally (Selaroides leptolepis). Food Science, 74(2), 126-133.

Kristinsson, H.G., \& Rasco, B. A. (2000). Fish protein hydrolysates: production, biochemical, and functional properties. Critical Reviews in Food Science and Nutrition, 40, 43-81.

Lee, S.H., Qian, Z.J., \& Kim, S.K. (2010). A novel angiotensin I converting enzyme inhibitory peptide from tuna frame protein hydrolysate and its antihypertensive effect in spontaneously hypertensive rats. Food Chemistry, 118(1), 96-102

Li, X., Kim, S.K., Nam, K.W., Kang, J.S., Choi, H.D., \& Son, B.W. (2006) A new antibacterial dioxopiperazine alkaloid related to gliotoxin from a marine isolate of 
the fungus Pseudallescheria. Antibiotics, 59(4), 248250.

Lowry, O.H., Rosbrough, N.J., Farr, A.L., \& Randall, R.J. (1951). Protein measurement with the folin fenol reagent. Biological Chemistry, 193(1), 265-275.

Luo, H.Y., Wang, B., Li, Z.R., Chi, C.F., Zhang, Q.H., \& He GY. (2013). Preparation and evaluation of antioxidant peptides from papain hydrolysates of Sphyrna lewini muscle protein. Food Science and Technology, 51, 281-288.

Mahmod, M.H., Ferial, M., Abu-Salema., El-Kalyoubib M.H., Gilbrielb A.Y. (2011). Bioactive compouns of fermented soybean natto as antioxidant and antimicrobial agents. Journal of. Food and Dairy Science 2(1): 59-70.

Mirdhayati, I., Hermanianto, J., Wijaya, C.H., Sajuthi, D., \& Arihara, K. (2015). Angiotensin converting enzyme (ACE) inhibitory and antihypertensive activities of protein hydrolysate from meat of Kacang goat (Capra aegagrus hircus). Science of Food and Agriculture, 96(10), 3536-3542.

Murray, B.A., \& FitzGerald, R.J. (2007). Angiotensin converting enzyme inhibitory peptides derived from food proteins: biochemistry, bioactivity and production. Current Pharmaceutical Design, 13(8), 773-91.

Nakamura, Y., Yamamoto, N., Sakai, K., Okubo, A., Yamazaki, S., \& Takano, T. (1995). Purification andcharacterization of angiotensin I-converting enzyme inhibitors from sour milk. Dairy Science, 78, 777-783.

Ngo, D.H., Vo, T.S., Ryu, B.M., \& Kim, S.K. (2016). Angiotensin-l-converting enzyme (ACE) inhibitory peptides from Pacific cod skin gelatin using ultrafiltration membranes. Process Biochemistry, 51(10), 1622-1628.

Nielsen, P.M., Petersen, D., \& Dambmann, C. (2001). Improved method for determining food protein degree of hydrolysis. Food Science, 66(5), 642-646.

Nurhayati, T., Desniar, \& Suhandana, M. (2013). Pembuatan pepton secara enzimatis menggunakan bahan baku jeroan ikan tongkol. Pengolahan Hasil Perikanan Indonesia. 16(1), 1-11.

Nurhayati, T., Salamah, E., \& Hidayat, T. (2007). Karakteristik hidrolisat protein ikan selar (Caranx leptolepis) yang diproses secara enzimatis. Buletin THP, 10(1), 23-34.

Nurhayati, T., Salamah, E., Cholifah, \& Nugraha, R. (2014). Optimasi proses pembuatan hidrolisat jeroan ikan Kakap Putih. Pengolahan Hasil Perikanan Indonesia, 17(1), 42-52.

Ovissipour, M., Safari, R., Motamedzadegan, A., \& Shabanpour, B. (2009). Chemical and biochemical hidrolysis of persian sturgeon (Acipenser persicus) visceral protein. Food and Bioprocess Technology, 5(2), 460-465.

Park, P.J., Jung, W.K., Nam, K.S., Shahidi, F., \& Kim, S.K. (2001). Purification and characterization of antioxidative peptides from protein hydrolysate of lechitin-free egg yolk. American Oil Chemists' Society, 78(6), 651-656.

Ranathunga, S., Rajapakse, N., \& Kim, S.K. (2005). Purification and characterization of antioxidative peptide derived from muscle of conger eel (Conger myriaster). European Food Research and Technology, 222(3-4), 310-315.

Ren, J., Zhao, M., Shi, J., Wang, J., Jiang, Y., Cui, C., Kakuda, Y., \& Xue, S.J. (2008). Purification and identification of antioxidant peptides from grass carp muscle hydrolysates by consecutes chromatography and electropsray ionization-mass spectrometry. Food Chemistry, 108(2), 727-736.

Riyanto, B., Uju, \& Halimi, S. (2012). Recovery of proteases from tuna viscera by ultrafiltration and reverse osmosis. Pengolahan Hasil Perikanan Indonesia, 15(2), 110-118.

Roslan, J., Siti, M.M.K., Yunos, K.F.Md., \& Abdullah, N. (2017). Assessment on multilayer ultrafiltration membrane for fractionation of tilapia by-product protein hydrolysate with angiotensin l-converting enzyme (ACE) inhibitory activity. Separation and Purification Technology, 173(1), 250-257.

Samaranayaka, A.G.P., Kitts, D.D., \& Li-Chan, E.C.Y. (2010). Antioxidative and angiotensin-l-converting enzyme inhibitory potential of a Pacific hake (Merluccius productus) fish protein hydrolysate subjected to simulated gastrointestinal digestion and caco-2 cell permeation. Agricultural and Food Chemistry, 58(3), 1535-1542.

Smith. D.M. (2017). Protein separation and characterization procedures. In Nielsen S (ed.), Food Analysis, Food Analysis Text Series (431-453) Indiana, US: Springer International Publishing

Toopcham, T., Mes, J.J., Wichers, H.J., Roytrakul, S., \& Yongsawatdigul, J. (2017). Bioavailability of angiotensin I-converting enzyme (ACE) inhibitory peptides derived from Virgibacillus halodenitrificans SK1-3-7 proteinases hydrolyzed tilapia muscle proteins. Food Chemistry, 220(1),190-197.

Valko, M., Leibfritz, D., Moncol, J., Cronin, M.T.D., Mazur, M., \& Telser, J. (2007). Free radical and antioxidant in normal physiological function and human disease. Biochemistry and Cell Biology, 39(1), 44-84.

Yadav, J.S.S., Yan, S., Ajila, C.M., Bezawada, J., Tyagi, R.D., \& Surampalli, R.Y. (2016). Food-grade singlecell protein production, characterization and ultrafiltration recovery of residual fermented whey proteins from whey. Food and Bioproducts Processing, 99(1), 156-165. 